\title{
Fibrosus dysplasia differenciál-diagnózisa
}

\author{
DR. SIMONFFY LÁSZLÓ, DR. GYULAI-GAÁL SZABOLCS, DR. DOBÓ NAGY CSABA, DR. SZABÓ BENCE TAMÁS
}

\begin{abstract}
A tanszékünkön megjelent 69 éves nőbeteg anamnézisének felvétele és stomato-onkológiai szürése után panoráma(OP) felvétel készült, amelyen multiplex szklerotikus, cystosus felritkulások láthatók a mandibulán. A tapasztalt elváltozások alapján további képalkotó modalitások alkalmazása vált indokolttá, így posteroanterior (PA) és oldalirányú (LAT) koponya-, illetve cone beam CT (CBCT) felvételeket készítettünk. A PA és LAT koponyafelvételeken kóros eltérés a mandibulán kívül egyéb területen nem ábrázolódott. Minthogy a páciens ötéven belül nem jelent meg tüdőszürő vizsgálaton, ezért nem rendelkezünk PA-mellkasfelvétellel. A páciens képanyaga alapján megerősítettük a fibrosus dysplasia radiológiai diagnózisát.

Kulcsszó: orthopantomographia, cone beam computed tomography, csont fibrosus dysplasia, monostoticus fibrosus dysplasia, differenciál diagnózis
\end{abstract}

\section{Bevezetés}

A fibrosus dysplasia (FD) a csontszövet többnyire jóindulatú tumorszerű fejlődési rendellenessége [1-4]. A csontvelő helyén fibrosus és éretlen osteoid szövet képződik („woven bone”) [4-6]. Weinstein és munkatársai leírták, hogy a zavart csontérési folyamat hátterében a Gsa fehérje alegységet kódoló GNAS1 génaktiváló mutációja áll [7], ami az osteblastok differenciálódásának gátlásához és azok abnormális proliferációjához vezet $[7,8]$. Az elváltozás a benignus csontdaganatok 2,5-7\%-át adja [2, 3]. A FD irodalmában többféle csoportosítási rendszer ismert [1, 3, 7], amelyekben közös, hogy a FD-t megjelenési helye szerint rendszerezik. A monostoticus FD, amelynek során csak egy csont érintett, sokkal gyakoribb (az összes FD esetek $70-80 \%-a)$, mint a több csontra kiterjedő polyostoticus forma [2, 9, 10], amely gyakran tovább növekszik a csontok érésének befejeződése után, és csontfájdalomhoz, súlyos deformitásokhoz vezethet, növelve a patológiás fractura kockázatát [2]. A FD leggyakrabban a hosszú csöves csontokban [2, 10, 11], a craniofaciális területen $[2,4,11]$, illetve a bordákon alakul ki $[2,10,11]$. A monostoticus FD-s esetek 10-25\%-ában, a polyiostoticus esetek 50\%-ában koponya- vagy arckoponyacsont érintett [12], de bármely csontban kialakulhat [4]. A monostoticus forma egyenletes eloszlást mutat mindkét nemben, a polyostoticus forma viszont többnyire fiatal nők körében gyakoribb [9]. A polyostoticus formához társulhat McCune Albright vagy Mazabraud szindróma [10]. Előbbi esetben az FD mellett fellép endocrinopathia, leggyakrabban pubertás praecox, illetve café au lait pigmentáció; utóbbi esetben pedig a polyostoticus FD intramuscularis myxomákkal társul [2, 9, 10, 13]. Egyes szerzők külön tárgyalják a craniofacialis FD-t [1, 3], ugyanis az itt kialakuló elváltozás radiológiai képe gyengén körülhatárolt és bizonyos esetekben tartalmazhat lamelláris csontot, míg az axiális csontok esetében inkább radiolucens és nem tartalmaz lamelláris csontot $[9,14]$.

A pontos diagnózis felállításához gyakran nem elegendő pusztán szövettani diagnózis megállapítása, hanem megfelelő radiológiai modalitás is szükséges [1]. A radiológiai kép változatos megjelenésú, amely a FD korai fázisában - tekintve a lítikus folyamatokat - inkább a radiolucens területek, míg a későbbi, a FD laesio érettebb állapotában a denzebb területek dominánsabbak $[13,15]$. A monostoticus FD többnyire tünetmentes és egyéb indikációjú radiológiai vizsgálat során derül rá fény [2]. A röntgenképe az alábbi három jellegzetességet mutathatja: $56 \%$-ban tejüvegszerü, $23 \%$-ban homogén denz és $21 \%$-ban cystosus (egy vagy többrekeszes) mintázatot [10, 12, 16]. Utóbbi esetben jellemző a héjszerű sclerotikus szél, amely az axiális csontokon detektálva fontos diagnosztikus értékkel bír $[14,17]$. $A z$ állcsontok esetén ez a sclerotikus határ lehet vékony, jól körülírt, ténylegesen cystát körülhatároló; gyakrabban bár vékony, de szabálytalan lefutású, illetve vastagabb, sávszerű opacitást mutathat többrekeszes radiolucens területetek körül [1]. A homogén denz formára jellemző lehet a narancshéj- vagy ujjlenyomatszerü rajzolat [14], amely fiatalabb korban és föleg a maxillán figyelhető meg és más elváltozásra nem jellemző, azaz csak a FD-ra specifikus [1]. A tejüvegszerú megjelenés gyakoribb felnőtt pácienseknél, lokalizációját tekintve inkább a maxillán jellemző, viszont hiányzik a narancshéj rajzolatnál jellemző szemcsézettség [13]. $\mathrm{Az}$ irodalomban fellelhető adatok alapján a legjellem- 


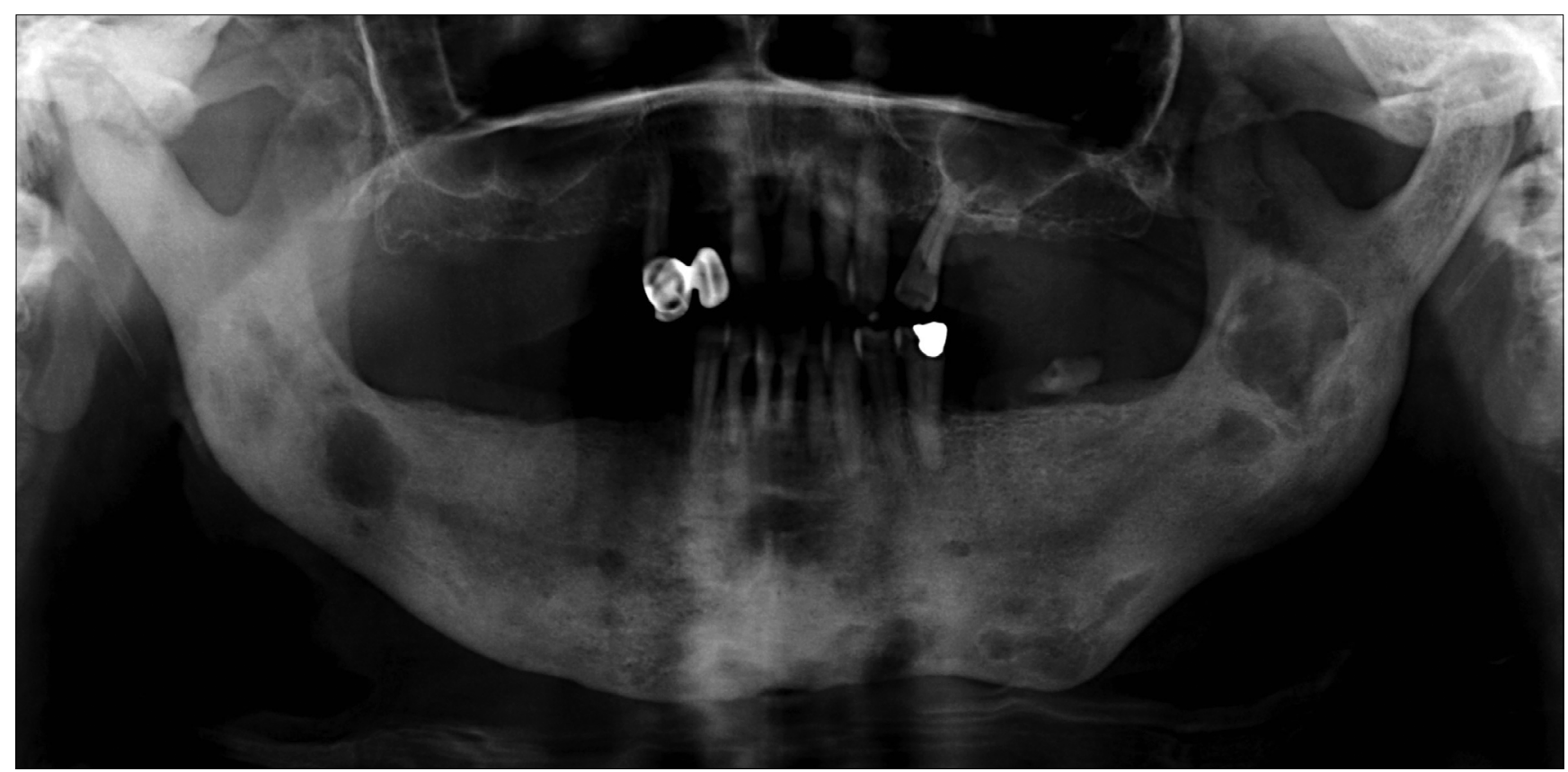

1 ábra: OP felvétel multiplex vegyes (radiolucens és radiopaque) elváltozással

zőbb a fent említett formákból álló kevert radiolucensradiopaque mintázat a craniofacialis régióban [13].

\section{Esetismertetés}

A tanszékünkön megjelent egyik páciens radiológiai képanyaga kapcsán tárgyaljuk az éles szélü radiológiai elváltozások radiológiai differenciál diagnózisát, illetve az eset kapcsán a páciens radiológiai diagnózisát. A 69 éves nőbeteg általános anamnézisében

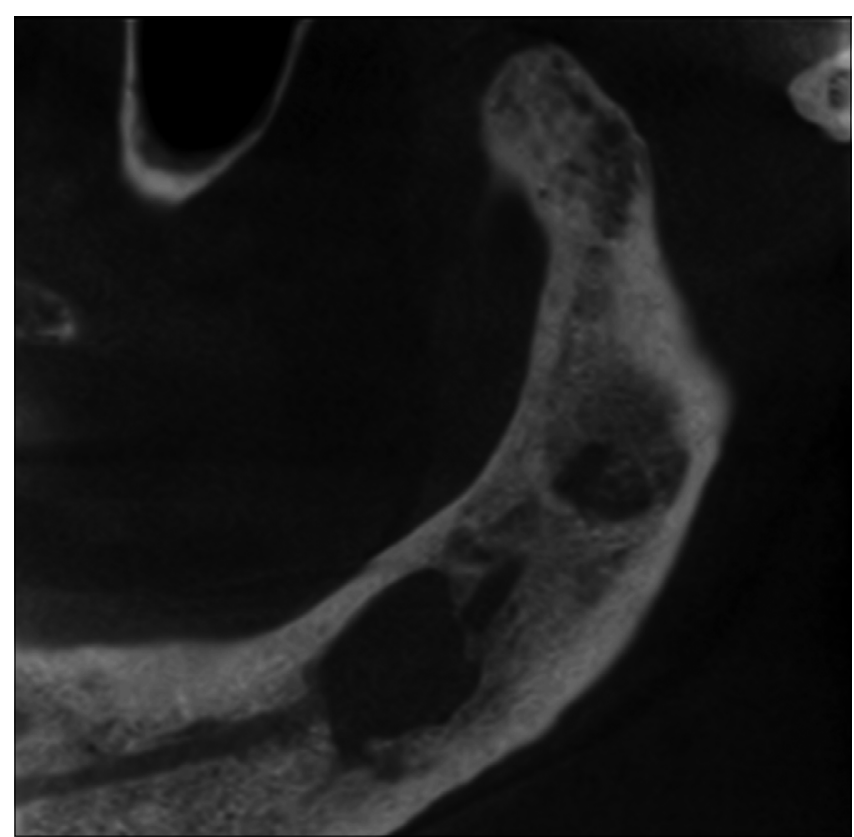

2 ábra: CBCT felvétel a jobb oldali mandibulafélen multiplex vegyes (radiolucens és radiopaque) elváltozással kezelt hypertonia szerepelt. A mozgásrendszer (csontváz- és izomrendszer) a páciens életkorának és nemének megfelelő, a légző- és emésztőrendszer kóros elváltozást nem mutatott. A páciens stomato-oncológiai szűrése után $\mathrm{OP}$ felvétel készült. A felvételén multiplex szklerotikus, cystosus felritkulások láthatók a mandibulán (1. ábra).

További vizsgálatok elvégzése után posteroanterior (PA) és oldalirányú (LAT) koponya-röntgenfelvételeket, illetve cone beam CT (CBCT) felvételeket készítettünk ( $150 \mu \mathrm{m}$ voxel méret, $5 \times 5 \times 5 \mathrm{~cm}$ FOV). A CBCT felvételeken a mandibulán jól körülírt, éles szélú kevert radiolucens és radiopaque területek detektálhatók (2. ábra). A bal oldali angulus mandibulaetól superior irányban, a ramus mandibulae alsó harmadában ujjlenyomatszerủ rajzolat található (3. ábra), középső harmadában pedig a szabálytalan alakú radiolucens laesióban, a laesio középpontjától anterosuperior irányban calcificatio ábrázolódik (3. ábra). A PA és LAT koponyafelvételeken kóros eltérés a mandibulán kívül, egyéb területen nem ábrázolódott.

\section{Megbeszélés}

Minthogy a páciens öt éven belül nem jelent meg tüdőszürő-vizsgálaton, ezért nem rendelkezünk PA mellkasfelvétellel, mely segíthet elkülöníteni a monostoticus, illetve polyostoticus formákat, habár meg kell jegyeznünk, hogy az állcsontokat érintő FD többnyire monostoticus természetű [1]. Csípő tájéki fájdalom esetén (leggyakoribb lokalizációja a betegségnek a collum femoris területe az axialis csontok közül [1]), amenynyiben a radiológiai csípő lelet pozitív, polyostoticus 


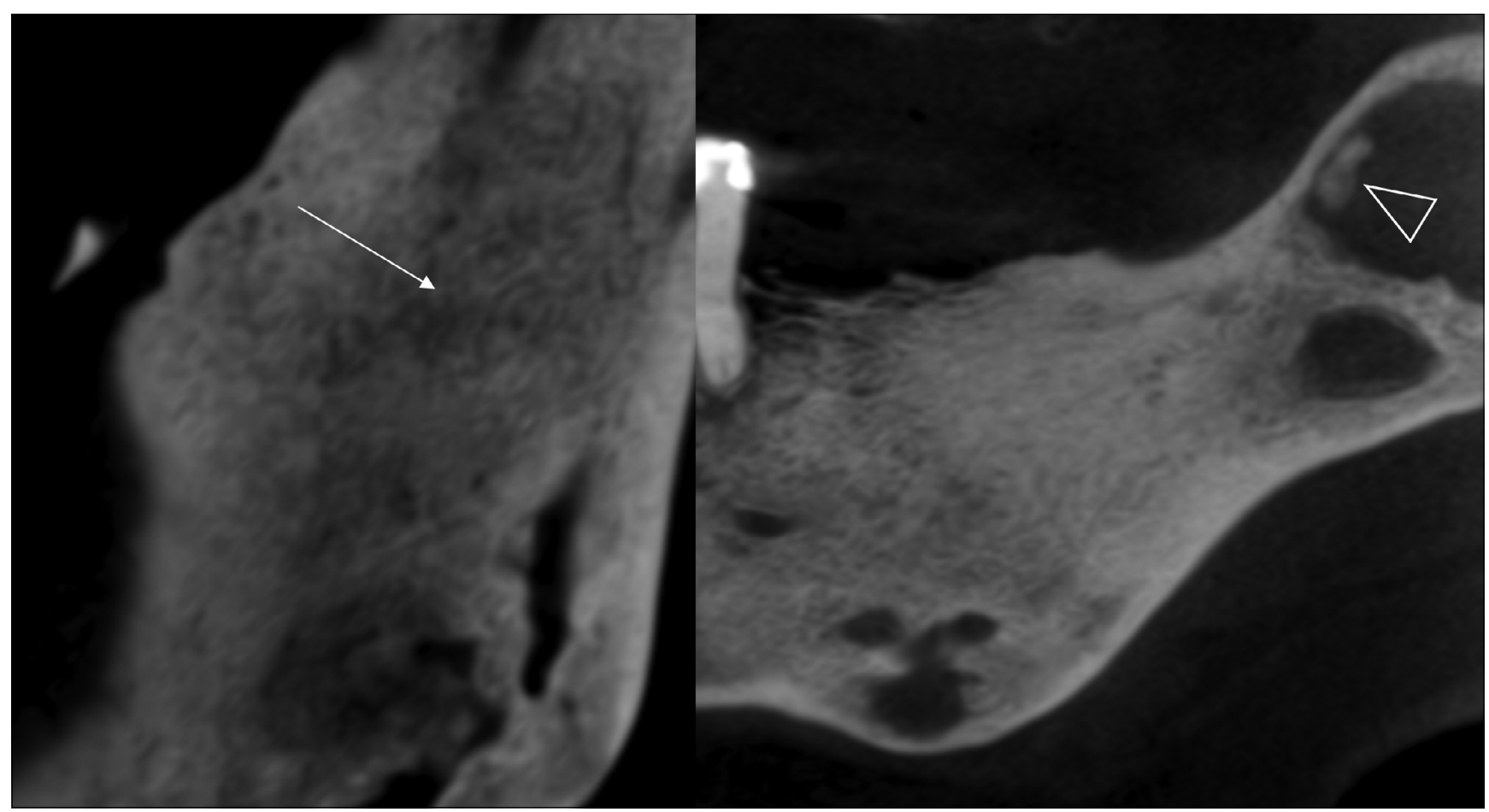

3 ábra: CBCT felvétel a bal oldali mandibulafélen multiplex, éles szélű radiolucens laesiók, az angulus tájékon a FD-ra jellemző ujjlenyomatszerü rajzolattal (fehér nyíl) és calcificatio (üres nyíl)

forma valószínúsíthető [2]. A páciens anamnézisében csak gyógyszeresen kezelt magas vérnyomás betegség áll, mozgásszerve korának megfelelően müködik, és sem emésztőszervi, sem légzőszervi panaszai nincsenek. Amennyiben a csontelváltozások panaszmentesek és évek óta fennállnak, elégséges a hosszú távú obszerváció. Szövettani mintavétel a beavatkozással járó szövődmények miatt nem szükséges ezen esetekben (csontnecrosis, osteomyelitis).

Ennek az esetnek a kapcsán számos differenciál diagnosztikus kérdés merül fel. Az ilyen jellegű, az egyes röntgenfelvételeken leírt elváltozások további vizsgálatok elvégzését indokolhatják. Alábbiakban röviden tekintsük át ezeket a kórképeket, amelyek hasonló radiológiai jeleket mutatnak.

Először az éles határral rendelkező radiolucens elváltozásokat kell számba venni. A radicularis cysta esetén az elváltozás fog eredetű gyulladás talaján keletkezik, az elhalt fog gyökércsúcsa körül. Minden életkorban előfordul, de leginkább a 30-60 évesek körében a leggyakoribb. Radiológiailag a fog gyökércsúcsa körül jól körülhatárolt radiolucens képletet látunk változatos méretben [18, 19, 21]. Extrém ritka esetben a cysta hámjának malignus transzformációja figyelhető meg intraossealis laphám carcinomát eredményezve. Röntgenképen benignus cysta képét mutatja. Residualis cysta esetén radicularis cysta visszamaradásáról beszélhetünk. A nem vitális gócos fog eltávolítása után maradhat viszsza. OP felvételen residualis cysta képének megfelel azzal a különbséggel, hogy nincs kapcsolata foggyökérrel. Méretben általában $1 \mathrm{~cm}$ vagy az alatti méretet ér el [21]. Follicularis cysta a 20-40 éves korosztályban a leggyakoribb, és a második leggyakrabban előforduló cystosus képlet. Retinealt fogak koronája körül alakul ki. Röntgenfelvételen az előtörésben visszamaradt fog körüli éles, scleroticus határú képletet látunk [18, 21]. Traumás cysták esetén nem beszélhetünk valódi cystáról. Olyan csontüregek, amelyeknek nincs hámbélése. Radiológiailag jól körülhatárolt, éles szélű kerek, radiolucens elváltozás képét látjuk [22]. Keratocysták esetén jóindulatú elváltozással állunk szemben, azonban az agresszív növekedési hajlama miatt gyakori recidívával kell számolni. Unilocularis és multilocularis elhelyezkedése lehet. Denzitásban lágyszöveti képet mutat a cysta bennéke jól körülírt határral. Involvált fogak esetén resorptio előfordul, ilyenkor ameloblastoma képét utánozhatja. Nagy méret esetén csontdeformitás is megfigyelhető az állcsontokban [18, 19, 22, 23]. A Stafne cystát a pseudocysták közé soroljuk. Radiológiailag éles határú radiolucens corticalist érintő deffektust látunk, jellemzően az angulus területén. Cysta radiológiai képét utánozhatja mucoepidermoid carcinoma is, amennyiben csontérintettség van. Az elváltozás extrém ritka. Az ameloblastoma szintén benignus, de lokálisan agresszív, viszont lassú növekedést mutató odontogen tumor. Általában a mandibula posterior régiójában manifesztálódik. Radiológiai megjelenése függ a szövettani típusától, uni- és multilocularis formák ismeretesek. Csontexpanzió, az érintett fogak resorptiója, ún. szappanbuborék („mézpergető”) jelek láthatók az elváltozásban. Differenciál-diagnosztikai szempontból gondolni kell centrális haemangiomára is. 
A centrális haemangioma, nagyon ritka manifesztációjú, nőket gyakrabban érintő elváltozás (nő:ffi arány 2:1). A tumor előfordulása a csontot érintő tumorok között 0,5$1 \%[18,20]$. Az osteomyelitis radiológiailag rosszul körülhatárolt csontelváltozás. Sequestratio, sclerotisatio és periostealis reakció figyelhetó meg. Sclerotisalo osteomyeltis elsősorban gyerekeket és fiatal felnőtteket érint, főleg a mandibulát involválja. Hátterében odontogén eredet áll. Eosinophil granuloma esetén Langerhans hystiocytosis áll a betegség hátterében. Az elváltozás benignus besorolást kapott. Az elváltozások száma és elhelyezkedése alapján három típus ismert. Unifocalis, multifocalis egyszervi és multifocalis többszervi érintettséggel. Lítikus csontlaesiók, diabetes insipidus és exophtalmus esetén a Hand-Schüller-Christian szindrómáról, míg a multilocularis többszervi érintettség esetén az Abt-Letterer-Siwe szindrómáról beszélhetünk. Csontérintettség szempontjából bármely csont involválódhat, de leggyakrabban a koponya, az állcsontok, a bordák és a hosszú csöves csontok érintettek. Az esetek 10\%-ban érintett a mandibula. Radiológiailag jól körülírt laesiókról beszélhetünk, reaktív sclerosisszal vagy anélkül. CBCT felvételen reaktív periostealis jelek láthatók. Változatos radiológiai képe miatt gondolni kell Ewing sarcoma, osteosarcoma és tumor metastasis megjelenésére is $[18,19,20,21,13]$. Az óriás sejtes granuloma egy benignus, de lokálisan agresszív proliferáló fibrotikus elváltozás. Tipikusan multilocularis, jól körülírt elváltozások formájában jelenik meg radiológiailag, a mandibula posterior régiójában gyakrabban fordul elő. A Paget-kór ismeretlen etiológiájú betegség. Radiológiailag osteolítikus területek váltakoznak sürübb csontszerkezetű területekkel. A maxillát gyakrabban érinti, mint a mandibulát [19]. Szóba jöhet még a Cherubismus, amely egy ritka megjelenésű betegség és a maxilla valamint a mandibula deformitásával jár, jellegzetes arcformát eredményezve. FD esetén a megjelenési helye szerint monostoticus és polyostoticus formákról beszélhetünk. Radiológiai képe a két elváltozásnak megegyezik, a fogak ritkán resorbeálódnak, habos vagy tejüvegszerū csontképet látni. Lehet kisméretű éles, és lehet multilocularis is az elváltozás [13, 23, 24]. Tekintve a fent említett egyes kórképek radiológiai jeleit biztos diagnózist csak hisztológiai mintavétel és diagnózis után lehet megállapítani. A radiológiai kép alapján az FD a legvalószínúbb diagnózis és ez felel meg a radiológiai diagnózisnak is. Az elváltozások méretbeli vagy számbeli növekedése esetén azonban a hisztológiai mintavétel elengedhetetlen a végső diagnózis és a kezelési terv felállításához.

Elmondhatjuk, hogy nem elégséges a betegvizsgálatnál csupán a szájüreg vizsgálata. Számos betegségnek extraoralis és többszervi tünetei is vannak, amelyeket a pontos, részletes anamnézisfelvétel során tárhatunk fel. Panorámafelvételek készítése esetén, megfelelő radiológiai jeleknél szükséges kiegészítő vizsgálatokat kérni, úgymint nagy felbontású $\mathrm{CBCT}$, MRI, UH vizsgálatokat is. Sem- miképp nem feledkezhetünk meg arról a tényröl, hogy nem a szájüreget gyógyítjuk, hanem az egész beteget.

A szerzőknek nincsenek érdekeltségeik.

\section{Irodalom}

1. Langlais RP, Langland OE, Nortjé CJ: Diagnostic Imaging of the jaws. Williams \& Wilkins, Malvern 1995; 578-588.

2. DiCaprio MR, Enneking WF: Fibrous dysplasia. Pathophysiology, evaluation, and treatment. J Bone Joint Surg Am. 2005; 87: 18481864.

3. Adetayo OA, Salcedo SE, Borad V, Richards SS, Workman, AD, RAY, AO: Fibrous dysplasia: an overview of disease process, indications for surgical management, and a case report. Eplasty. 2015. 15: p.e6.

4. Penn DL, Tartarini RJ, Glass CH, De Girolami U, Zamani AA, Dunn IF: Natural history of cranial fibrous dysplasia revealed during longterm follow-up: Case report and literature review. Surg Neurol Int. 2017; 8: 209.

5. Lichtenstein L, JafFe HL: Fibrous dysplasia of bone. A condition affecting one, several or many bones, the graver cases of which may present abnormal pigmentation of skin, premature sexual development, hyperthyroidism or still other extraskeletal abnormalities. Arch Pathol. 1942; 33: 777-816.

6. Lichtenstein L: Polyostotic fibrous dysplasia. Arch Surg. 1938; 36 : 874-898.

7. WeInSteIn LS, Chen M, LIU J: Gs(alpha) mutations and imprinting defects in human disease. Ann N Y Acad Sci. 2002; 968: 173-197.

8. Bianco P, Robey PG: Diseases of bone and the stromal cell lineage. J Bone Miner Res. 1999; 14 (3): 336-341.

9. Speight P, Carlos R: Maxillofacial fibro-osseous lesions. Diagn Histopathol. 2006; 12 (1): 1-10.

10. DeÁk M, Lombay B: Fibrosus dysplasia. MRO. 2013; 4 (11) doi: 10.5374/mro.2013.11.04

11. Hudson TM, Stiles RG, Monson DK: Fibrous lesions of bone. Radiol Clin North Am. 1993; 31 (2): 279-297.

12. Dobre MC, Fischbein N: 'Do not touch' lesions of the skull base. J Med Imaging Radiat Oncol. 2014; 58 (4): 458-463.

13. Gupta D, Garg P, Mittal A: Computed Tomography in Craniofacial Fibrous Dysplasia: A Case Series with Review of Literature and Classification Update. Open Dent J. 2017; 11 (Supp-I, M7): 384-403.

14. MACDONALD-JANKOWSKI DS: Fibro-osseous lesions of the face and jaws. Clin Radiol. 2004; 59: 11-25.

15. MacdonAlD-JankowsKI DS, LI TK: Fibrous dysplasia in a Hong Kong community: the clinical and radiological features and outcomes of treatment. Dentomaxillofac Radiol. 2009; 38 (2): 63-72.

16. Brown EW, Megerian CA, McKenna MJ, Weber: Fibrous dysplasia of the temporal bone. AJR Am J Roentgenol. 1995; 164: 679-682.

17. Eversole LR: Craniofacial fibrous dysplasia and ossifying fibroma. Oral Maxillofac Clin Nor Am. 1997; 9: 625-642.

18. Miloro M, Ghali GE, Larsen P, Waite P: Peterson's Principles of Oral and Maxillofacial Surgery. (3rd ed.) PMPH, Shelton 2004; 598-613.

19. SzAвó Gy: Szájsebészet, maxillofacialis sebészet. (3rd ed.) Semmelweis Kiadó, Budapest 2004; 289-295.

20. MARTonfFy K: Fogászati radiológia. (2nd ed.) Semmelweis Kiadó, Budapest 2010; 205-223.

21. Silva BSF, Bueno MR, Yamamoto-Silva FP, Gomez RS, Peters OA, EstRELA C: Differential diagnosis and clinical management of periapical radiopaque/hyperdense jaw lesions. Braz Oral Res. 2017; 31: e52.

22. Flores IL, Hamilton ME, Zanchin-Baldissera E, Uchoa-Vasconcelos AC, Chaves-Tarquinio SB, Neutzling-Gomes AP: Simple and aneurysmal bone cyst: Aspects of jaw pseudocysts based on an experience of Brazilian pathology service during 53 years. Med Oral Patol Oral Cir Bucal. 2017; 22 (1): e64-e69. 
23. Raubenheimer EJ, Noffke CE, Boy SC: Osseous Dysplasia with Gross Jaw Expansion: A Review of 18 Lesions. Head Neck Pathol. 2016; 10 (4): 437-443.
24. Metwally T, Burke A, Tsai JY, Collins MT, Boyce AM: Fibrous Dysplasia and Medication-Related Osteonecrosis of the Jaw. J Oral Maxillofac Surg. 2016; 74 (10): 1983-1999.

\section{SimonfFy L, Gyulai-GaÁl Sz, Dobó Nagy Cs, Szabó BT}

\section{Differential diagnosis of fibrous dysplasia}

Following taking the medical and dental history and performing a stomato-oncological screening of a 69-year-old female patient referred to our department, a panoramic X-ray acquisition was taken. On the panoramic image multiple sclerotic and cyst-like lesions were visible in the mandible. Based on the radiological findings, the use of further imaging modalities was needed. Posteroanterior (PA) and lateral (LAT) skull and cone beam CT (CBCT) images were taken. Except for the mandibular bone no abnormalities were found in other areas of the skull on the PA and LAT skull radiographs. No chest $X$-ray acquisition has been taken from the patient within the last five years. On the basis of available medical history, patient's examination data and radiographic images monostotic fibrous dysplasia has been predicted as radiologic diagnosis. Fibrous dysplasia is a benign developmental failure of the bone, which can involve one (monostotic type) or more bones (polyostotic type). During the bone remodeling the osseus structures are replaced by immature fibro-osseous tissue. A precise diagnosis of fibrous dysplasia usually cannot be made without using appropriate radiologic imaging modalities.

Keywords: orthopantomography, cone beam computed tomography, fibrous dysplasia of bone, monostotic fibrous dysplasia, differential diagnosis

\section{A Szakmai Kollégium Fog- és Szájbetegségek Tagozatának és Tanácsának állásfoglalása a fluorid tabletta indikációjával és adagolásával kapcsolatban}

A fluoridprevencióról nagyon régóta éles vita folyik a szakmai körökön belül. Manapság azonban lényegesen könnyebb helyzetben vagyunk, mint korábban, mert rendelkezésre állnak azok a módszerek - itt az evidencia-szintek meghatározásáról és alkalmazásáról van szó -, melyekkel objektív módon állapíthatjuk meg egy-egy közlemény „súlyát”. A Szakmai Kollégium Tagozata és Tanácsa által elfogadott, alább olvasható Álásfoglalása a közlemények evidencia-szintjeinek figyelembevételével készült. Tekintve, hogy a fluoridtabletták indikációja és adagolása csak egy része a fluoridprevenciónak, a fluoridprevencióról átfogó állásfoglalás készítése szükséges. Azonban a fluoridtablettákkal kapcsolatban volt a legsürgősebb a korszerű álláspont meghatározása, hiszen annak alkalmazása viszonylag gyakori kérdés. Szükségesnek tűnt a gyermekorvosok bevonása és tájékoztatása is, mert a szülők sokszor hozzájuk fordulnak ebben az ügyben. Kívánatos, hogy minden lehetséges csatornán azonos, mai tudásunknak megfelelő információhoz lehessen hozzájutni, ehhez kíván biztos alapot nyújtani az alábbi Állásfoglalás.

\section{A Szakmai Kollégium \\ Fog- és Szájbetegségek Tagozatának és Tanácsának állásfoglalása a fluorid tabletta indikációjával és adagolásával kapcsolatban}

1. A fogszuvasodás nem fluorid hiánybetegség.

2. Hatéves kor alatt a fluorid tabletta cariesprevenciós hatékonysága nem bizonyított, kizárólag a szakma szabályai szerint magas caries rizikójúnak tekinthető gyermekeknek célszerű adni. A caries rizikó megítélése fogorvos kompetenciája.

3. Az adagolása ebben az esetben, ha az ivóvíz fluoridtartalma kevesebb, mint 0,5 ppm, évi 200 napon át a háromtól hat éveseknél napi egy, a hat-tizenhat éveseknél napi kettő 0,23/0,25 mg fluoridot tartalmazó tabletta.

4. Az adagolás meghatározásakor az egyéb fluoridforrásokat is figyelembe kell venni, a fokozott fluorózis rizikó kb. nyolcéves korig áll fenn.

5. Akut túladagolás esetén súlyos toxikus tünetek alakulhatnak ki.

6. Nem célszerü továbbra is vény nélkül forgalmazni, legyen vényköteles.
Prof. Dr. Fejérdy Pál Tagozatelnök
Prof. Dr. Hermann Péter Tanácselnök

Dr. Bartha Károly

Magyar Preventív Fogászati Társaság elnöke 